\title{
PENGARUH OMZET PENGHASILAN, TARIF PAJAK, SERTA SELF ASSESSMENT SYSTEM TERHADAP KEPATUHAN WAJIB PAJAK USAHA MIKRO, KECIL DAN MENENGAH (UMKM) DI KOTA TEGAL
}

(Studi pada Wajib Pajak Usaha Mikro, Kecil dan Menengah yang Terdaftar di Kantor Pelayanan Pajak Pratama Kota Tegal)

\author{
Putri Rizqiyah Yuliyanah, Dien Noviany R dan Baihaqi Fanani \\ Fakultas Ekonomi dan Bisnis \\ Universitas Pancasakti
}

\begin{abstract}
The influence of earning turnover, tax rate and self assessment system on taxpayer compliance of SMSe in Tegal City. (Study on tax payers of Micro, Small, and Medium Enterprises registered in KPP Pratama Tegal). Undergraduate Thesis. Tegal: Faculty of Economics and Bussines, Pancasakti University, Tegal. 2018.

The purpose of this research is to the influence of income, tax rate, and self assessment system on taxpayer compliance SMEs in Tegal City. The sample in this research are 83 respondents there are is a bussines owners, micro, small, and medium in Tegal City.

This research were collected through is quetionnaires. The test Instrument reliability in this research includes, validity test and reliability test. The test of Classic assumption include normality test, multicolinearity test, and heteroscedasticity test. For hypothesis test, we are using multiple linear regression analysis.

The results of this research showed that the variable turnover income and self assessment system have simultaneously (together) effect on taxpayer compliance SMEs in Tegal City with a significance value of 0.000. Partially on variable earning turnover have effect on compliance taxpayer SMEs in Tegal City with a significance value of 0,000, variable taxe rate have effect on taxpayer compliance SMEs in Tegal City with a significance value of 0,035, and variable self assessment system have effect on taxpayer compliance SMSe in Tegal City with significance value of 0,011 .
\end{abstract}

Keywords: Income Turnover, Tax Rate, Self Assessment System, Taxpayer Compliance

\section{A. PENDAHULUAN}

\section{Latar Belakang}

Dalam suatu pemerintahan, pendapatan negara merupakan elemen yang penting. Pendapatan berfungsi untuk keberlangsungan pembangunan serta pembiayaan segala kegiatan operasional pemerintah baik untuk kegiatan operasional di dalam negeri maupun di luar negeri. Salah satu sumber dari pendapatan negara terbesar adalah pajak. Mardiasmo $(2016 ; 1)$ mengatakan pajak merupakan iuran rakyat kepada negara dan yang berhak memungut hanya negara, diatur dalam undang-undang perpajakan dan dapat dipaksakan, akan tetapi rakyat tidak mendapatkan jasa timbal balik secara langsung yang dapat dirasakan atau ditunjukan, serta iuran tersebut digunakan untuk membiayai rumah tangga negara, yaitu segala pengeluaran yang bermanfaat bagi masyarakat luas (Mardiasmo, 2016; 1).

UMKM adalah salah satu penyumbang pajak di Indonesia. UMKM 
mempunyai peranan penting dan strategis dalam pembangunan ekonomi nasional. UMKM juga berperan dalam penyerapan tenaga kerja, serta mendistribusikan hasil-hasil pembangunan, hal tersebut tentu dapat menimbulkan peningkatan pendapatan masyarakat, mendorong pertumbuhan ekonomi negara, serta dapat tercipta stabilitas nasional (LPPI, 2015; 1)

Namun penerimaan pajak pada sektor UMKM belum maksimal, Prastowo berpendapat bahwa bagi kebanyakan UMKM tarif pajak sebesar $1 \%$ itu terlalu besar dan memberatkan mereka sehingga mengurangi tingkat kepatuhan mereka dalam membayar pajak. Tidak adanya timbal balik yang mereka rasakan secara langsung dapat juga menjadi salah satu pertimbangan mereka sehingga mengurangi tingkat kepatuhan mereka dalam membayar pajak. (Prastowo, dalam CITA, 2018)

Menurut Robbins dan Judge (2008) dalam Megantara, dkk (2017) mengatakan, teori atribusi menjelaskan bahwa individu melakukan pengamatan terhadap perilaku yang dilakukan seseorang karena pertimbangan internal maupun eksternal. Pertimbangan secara internal adalah perilaku yang diyakini berada di bawah kendali pribadi individu itu sendiri atau berasal dari faktor internal seperti ciri kepribadian, kesadaran, dan kemampuan. Salah satu faktor internal dalam penelitian ini yaitu omzet penghasilan dan 2 variabel eksternal lagi yang di anggap dapat mempengaruhi kepatuhan wajib pajak UMKM dalam membayar pajak sebagai faktor eksternal yaitu tarif pajak serta self assessment system.

Dari uraian latar belakang di atas, dalam penelitian ini peneliti bermaksud untuk meneliti tentang bagaimana peranan tiga variabel di atas yaitu tarif pajak, omzet penghasilan, serta penerapan self assessment system dalam kepatuhan wajib pajak khusunya UMKM. Sehingga peneliti mengambil judul dalam penelitian ini yaitu "PENGARUH OMZET PENGHASILAN, TARIF PAJAK, SERTA SELF ASSESSMENT SYSTEM TERHADAP KEPATUHAN WAJIB PAJAK USAHA MIKRO KECIL DAN MENENGAH DI KOTA TEGAL".

\section{Rumusan Masalah}

Berdasarkan uraian latar belakang yang telah dijelaskan di atas, maka rumusan masalah dalam penelitian ini adalah sebagai berikut:

1. Apakah terdapat pengaruh secara simultan dari omzet penghasilan, tariff pajak, serta self assessment system terhadap kepatuhan wajib pajak UMKM?

2. Apakah terdapat pengaruh secara parsial dari omzet penghasilan terhadap kepatuhan wajib pajak UMKM?

3. Apakah terdapat pengaruh secara parsial dari tarif pajak terhadap kepatuhan wajib pajak UMKM?

4. Apakah terdapat pengaruh secara parsial dari penerapan self assessment system terhadap kepatuhan wajib pajak UMKM?

\section{Tujuan Penelitian}

Berdasarkan perumusan masalah di atas maka tujuan dari penelitian ini adalah sebagai berikut:

1. Untuk mengetahui apakah terdapat pengaruh secara simultan dari omzet penghasilan, tarif pajak, serta penerapan self assessment system terhadap tingkat kepatuhan wajib pajak UMKM.

2. Untuk mengetahui apakah terdapat pengaruh secara parsial dari omzet 
penghasilan terhadap kepatuhan wajib pajak UMKM.

3. Untuk mengetahui apakah terdapat pengaruh secara parsial dari tarif pajak terhadap kepatuhan wajib Pajak UMKM.

4. Untuk mengetahui apakah terdapat pengaruh secara parsial dari penerapan self assessment system terhadap kepatuhan wajib pajak UMKM.

\section{B. TINJAUAN PUSTAKA}

\section{Landasan Teori Pajak}

Menurut Undang-Undang Nomor 16 tahun 2009 mengenai Ketentuan Umum dan Tata Cara Perpajakan pada pasal 1 ayat 1 dalam Mardiasmo $(2016 ; 1)$ pajak adalah kontribusi wajib kepada negara yang terutang oleh orang pribadi atau badan yang bersifat memaksa berdasarka Undang-Undang, degan tidak mendapatkan imbalan secara langsung dan digunakan untuk keperluan Negara bagi sebesar-besarnya kemakmuran rakyat. (Mardiasmo, 2016; 1)

\section{Pajak Penghasilan}

Berdasarkan Undang-Undang Republik Indonesia Nomor 36 Tahun 2008 Pasal 4: salah satu yang menjadi objek pajak adalah penghasilan, yaitu setiap tambahan kemampuan ekonomis yang diterima atau diperoleh wajib pajak, baik yang berasal dari Indonesia maupun dari luar Indonesia, yang dapat dipakai untuk konsumsi atau untuk menambah kekayaan wajib pajak yang bersangkutan, dengan nama dan dalam bentuk apa pun. Dalam Undang-Undang Republik Indonesia Nomor 36 Tahun 2008 Pasal 14 disebutkan sebagai berikut:

1. Norma penghitungan penghasilan neto untuk menentukan penghasilan neto, dibuat dan disempurnakan terus-menerus serta diterbitkan oleh Direktorat Jenderal Pajak.

2. Wajib pajak orang pribadi yang melakukan kegiatan usaha atau pekerjaan bebas dengan peredaran bruto dalam 1 tahun kurang dari Rp 4.800.000.000,00 boleh menghitung penghasilan neto dengan menggunakan norma penghitungan penghasilan neto sebagaimana dimaksud pada ayat (1), dengan syarat memberitahukan kepada direktorat jenderal pajak dalam jangka waktu 3 bulan pertama dari tahun pajak yang bersangkutan.

\section{Penghasilan Kena Pajak}

Berdasarkan Undang-Undang Perpajakan Pasal 17 tentang Penghasilan Kena Pajak (2013; 64) yang berlaku hingga saat ini. Berikut adalah tarif pajak yang diterapkan atas Penghasilan Kena Pajak bagi beberapa masing-masing wajib pajak:

Wajib pajak orang pribadi dalam negeri adalah sebagai berikut:

\section{Tabel 1 Tarif Pajak WPOP}

\begin{tabular}{|l|c|}
\hline \multicolumn{1}{|c|}{ Lapisan Penghasilan Kena Pajak } & Tarif Pajak \\
\hline Sampai dengan Rp 50.000.000.000,00 & $5 \%$ \\
\hline $\begin{array}{l}\text { Diatas Rp 50.000.000.000,00 sampai } \\
\text { dengan Rp 250.000.000,00 }\end{array}$ & $15 \%$ \\
\hline $\begin{array}{l}\text { Diatas Rp 250.000.000,00 sampai dengan } \\
\text { Rp 500.000.000,00 }\end{array}$ & $25 \%$ \\
\hline Diatas Rp 500.000.000,00 & $30 \%$ \\
\hline
\end{tabular}

Pajak Penghasilan yang diatur oleh PP Nomor 46 Tahun 2013.

PP Nomor 46 tahun 2013 tentang $\mathrm{PPh}$ Pasal 4 ayat (2) bersifat final, maksudnya adalah setoran yang harus dibayar adalah PPh Pasal 4 ayat 2 bukan $\mathrm{PPh}$ Pasal 25. Apabila penghasilan semata-mata dikenai $\mathrm{PPh}$ final, maka tidak wajib untuk PPh Pasal 25.

Peraturan Pemerintah (PP) Nomor 46 Tahun 2013 pasal 4 ayat 2 adalah suatu kebijakan Pemerintah yang mengatur mengenai pajak penghasilan 
atas penghasilan dari usaha yang diterima atau diperoleh wajib pajak yang memiliki peredaran bruto tertentu. Wajib pajak yang dikenai Pajak Penghasilan Nomor 46 Tahun 2013 pasal 4 ayat 2 ini adalah penghasilan dari usaha yang diterima atau diperoleh wajib pajak dengan peredaran bruto (omzet) yang tidak melebihi $\mathrm{Rp}$ 4,8 miliar dalam 1 tahun pajak. Objek peredaran bruto berdasarkan PP Nomor 46 Tahun 2013 adalah omzet seluruh gerai, counter, outlet atau sejenisnya baik pusat maupun cabangnya.

Atas dasar PP Nomor 46 tahun 2013 tentang PPh Pasal 4 ayat 2, Pajak yang terutang dan harus dibayar adalah $1 \%$ dari jumlah peredaran bruto. Jumlah peredaran bruto yang dimaksud di antaranya meliputi usaha dagang, industri, dan jasa, misalnya toko, kios, los kelontong, pakaian, elektronik, bengkel, penjahit, warung atau rumah makan, salon, dan usaha lainnya.

\section{Usaha Mikro, Kecil, dan Menengah}

IKAPI (2010) memberikan pendapat bahwa Usaha Mikro, Kecil, dan Menengah adalah kegiatan usaha yang dapat memperluas lapangan pekerjaan serta memberikan pelayanan ekonomi secara luas kepada masyarakat, berperan dalam proses pemerataan dan peningkatan pendapatan masyarakat, memicu pertumbuhan ekonomi, dan berperan dalam mewujudkan stabilitas ekonomi nasional. Selain itu, IKAPI (2010) juga mengatakan bahwa Usaha Mikro, Kecil, dan Menengah merupakan salah satu pilar utama ekonomi nasional yang harus memdapatkan kesempatan utama, dukungan, perlindungan serta pengembangan seluas- luasnya sebagai salah satu wujud keberpihakan pemerintah terhadap kelompok usaha ekonomi rakyat, tanpa mengabaikan peranan untuk Usaha Besar dan Badan
Usaha Milik Negara. (Ikatan Penerbit Indonesia, 2010).

Menurut Bank Dunia dalam (LPPI, 2015; 12) karakteristik UMKM dapat dikelompokan dalam tiga jenis, yaitu:

1. Usaha Mikro yaitu usaha dengan jumlah karyawan sebanyak 10 orang.

2. Usaha Kecil yaitu usaha dengan jumlah karyawan sebanyak 30 orang.

3. Usaha Menengah yaitu usaha dengan jumlah karyawan sebanyak 50-300 orang.

Menurut LPPI (2015; 12) klasifikasi UMKM dalam prespektif usahanya dikategorikan ke dalam empat kelompok, yaitu sebagai berikut:

1. UMKM pada sektor informal, yaitu contohnya seperti pedagang kaki lima.

2. UMKM Mikro merupakan para UMKM dengan kemampuan memiliki sifat pengrajin namun kurang memiliki jiwa kewirausahawan untuk mengembangkan usahanya.

3. Usaha Kecil Dinamis merupakan UMKM yang memiliki kemampuan berwirausaha dengan menjalin kerja sama (dapat menerima pekerjaan sub kontrak) dan juga ekspor.

4. Fast Moving Enterprise merupakan UMKM yang mempunyai kemampuan kewirausahawan yang cakap atau baik dan telah siap bertransformasi menjadi usaha besar.

\section{Kepatuhan Wajib Pajak}

Kepatuhan wajib pajak adalah suatu keadaan dimana wajib pajak memenuhi semua kewajiban perpajakan dan melaksanakan hak perpajakannya sesuai dengan isi dan jiwa undangundang perpajakan. (Nurmantu, 2003; 
Mukzim, dkk. 2014 dalam Anggara dan Sulistiyanti, 2017; Mardiasmo 2016; 26) Variabel ini diukur dengan memodifikasi indikator wajib pajak patuh menurut Nasucha (2004: 9), dalam fatmawati (2015) dan Suandy (2011; 97) dalam Marina (2015) yang disesuaikan dengan Ketentuan umum dan tata cara perpajakan dalam Mardiasmo (2016; 23) yaitu meliputi:

1. Pendaftaran NPWP, artinya pelaku UMKM terdaftar sebagai wajib pajak dan memiliki Nomor Pokok Wajib Pajak (NPWP).

2. Wajib pajak memahami Ketentuan Umum dan Tata Cara perpajakan yang berlaku di Indonesia.

3. Wajib Pajak membayar pajak terutang, sesuai dengan kewajiban pajak terutangnya.

4. Tidak memiliki tunggakan pajak, artinya wajib pajak selalu memenuhi kewajiban perpajakannya tepat waktu.

5. Melaporkan SPT massa, artinya yaitu wajib pajak membayar pajak terutang dan melaporkan SPT masa.

6. Melakukan pelunasan pajak kurang bayar, artinya wajib pajak melakukan pembayaran pelunasan atas pajak kurang bayar apabila wajib pajak memiliki kewajiban kurang bayar.

7. Menerapkan pencatatan atau pembukuan, artinya wajib pajak melakukan pencatatan dan pembukuan sesuai dengan ketentu.

8. Mentaati pemeriksaan pajak, artinya wajib pajak sukarelaa dan mentaati apabila diadakannya pemeriksaan pajak atas dirinya.

9. Memberikan keterangan yang diperukan, artinya wajib pajak harus mau memberikan keterangan yang diperlukan oleh pihak pemungut pajak ataupun saat dilakukan pemeriksaan pajak.

\section{Omzet Penghasilan}

Omzet penjualan adalah seluruh jumlah penjualan suatu produk barang atau jasa yang diperoleh dalam kurun waktu tertentu, dan dihitung berdasarkan jumlah uang yang diterima secara terus menerus dalam satu proses akuntansi. (Swastha 1993, Chaniago 1998, Anggara dan Sulistiyani, 2017)

Variabel ini diukur dengan menggunakan indikator menurut mufti (2010) dalam Chaerunnisa (2010) sebagai berikut:

1. Penghasilan merupakan objek pajak, artinya wajib pajak UMKM paham dan setuju bahwa berpapun omzet penghasilan yang mereka terima merupakan objek pajak.

2. Kemauan wajib pajak dalam mematuhi peraturan $\mathrm{PPh}$ final artinya adalah wajib pajak UMKM memahami serta mematuhi peraturan perpajakan yang berkaitan dengan UMKM yaitu diterapkannya $\mathrm{PPh}$ final bagi UMKM dengan penghasilan tertentu.

3. Membayar pajak berdasarkan omzet, yaitu saat ini wajib pajak membayar pajak berdasarkan omzet yang mereka terima, tidak mengacu pada PPh final atau PPh pasal 4 ayat 2.

4. Omzet yang tinggi maka pajaknya juga tinggi, artinya pembayaran pajak terutang tergantung pada setiap kenaikan omzet yang diterima wajib pajak UMKM setiap tahunnya.

5. Kebenaran dalam penyampaian penghasilan artinya wajib pajak UMKM secara transparan dengan jujur menghitung, dan melaporkan omzet besar kecilnya omzet dengan benar. 
6. Membuat pembukuan untuk menghitung omzet, UMKM melakukan pembukuan guna untuk melihat dan mengitung omzet yang mereka terima.

7. Semakin lama UMKM berdiri maka kualitas produknya, artinya semakin lama UMKM tersebut berdiri makanya akan meningkatkan kualitas produk karena terus melakukan perbaikan.

8. Semakin lama UMKM berdiri maka semakin tinggi pula omzet artinya semakin lama UMKM berdiri maka penghasilan yang diterima oleh wajib pajak UMKM semakin tinggi juga.

9. Semakin lama UMKM berdiri maka semakin baik pula dalam penguasaan pasar serta perkembangan teknologi yang ada.

\section{Tarif Pajak}

Sudirman dan Amirudin menyatakan tarif pajak adalah ketentuan persentase (\%) atau jumlah (rupiah) pajak yang harus dibayar oleh wajib pajak sesuai dengan dasar pajak atau objek pajak. (Sudirman dan Amirudin, 2012; 9 dalam Ananda dkk, 2015)

Variabel ini diukur menggunakan modifikasi indikator menurut Abidin (2016); Wahyuningsih (2016); dan Julianto (2017) untuk mengukur bagaimana pengenaan mengenai tarif pajak yaitu sebagai berikut:

1. Keadilan dalam penentuan tarif pajak artinya adalah bahwa tarif pajak yang saat ini telah ditetapkan sudah sesuai dan adil bagi para pelaku UMKM.

2. Pengenaan tariff $1 \%$ sebagai dasar pengenaan pajak artinya adalah pengenaan tarif $1 \%$ tersebut disetujui dengan baik bagi wajib pajak
UMKM atau justru memberatkan beberapa UMKM.

3. Pengenaan tarif $1 \%$ atas $\mathrm{PPh}$ final meringankan wajib pajak UMKM.

4. Penurunan tarif baru untuk omzet UMKM tertentu, artinya adalah akan ada penurunan tarif untuk setiap lapisan UMKM dengan menyesuaikan kondisi UMKM.

5. Tarif yang rendah meningkatkan kepatuhan wajib pajak UMKM, artinya jika benar akan terjadi penurunan tarif untuk wajib pajak UMKM dari $1 \%$ ke tarif tertentu maka akan meningkatkan kepatuhan wajib pajak UMKM dalam membayar pajak terutangnya.

6. Sosialisasi penurunan tarif pajak baru selalu dilakukan keseluruh lapisan wajib pajak.

7. Pengenaan tarif saat ini sudah sesuai dengan kemampuan UMKM, artinya untuk mengukur sejauh mana tarif $1 \%$ apakah sudah sesuai dengan kondisi setiap lapisan wajib pajak UMKM atau belum.

8. Tarif pajak tinggi menyebabkan kecurangan wajib pajak JMKM, artinya apabila tariff yang saat ini berlaku dirasa terlalu tinggi akan membuat wajib pajak UMKM melakukan kecurangan agar dapat membayar dengan nilai yang serendah-rendahnya.

9. Tarif yang berlaku dikenakan berbeda-beda tergantung sejumlah omzet penghasilan yang diterima wajib pajak UMKM.

\section{Self Assesment System}

Mardiasmo (2016; 9) mengatakan bahwa self assessment system Suatu sistem pemungutan pajak di mana wewenang sepenuhnya diberikan 
kepada wajib pajak untuk menentukan sendiri besarnya pajak terutangnya

Memiliki ciri-ciri sebagai berikut:

1. Wewenang untuk menentukan besarnya pajak terutang ada pada wajib pajak.

2. Wajib pajak aktif, yaitu wajib pajak melakukan perhitungan, menyetor, dan melaporkan sendiri pajak terutangnya.

3. Peran fiskus hanya mengawasi tidak ikut campur dalam hal apapun.

Penelitian ini diukur menggunakan indikator menurut Mardiasmo (2016;9) untuk mengukur bagaimana implementasi self assessment system yaitu sebagai berikut:

1. Kesadaran wajib pajak dalam memenuhi kewajiban pajaknya, artinya wajib pajak tahu dan mengerti bagaimana sistem pemungutan pajak yang diterapkan di Indonesia serta tanggung jawab atas kewajibannya.

2. Tanggung jawab dalam pengelolaan pajaknya, artinya wajib pajak bertanggung jawab atas semua pengelolaan pajak terutang yang ia kelola sendiri.

3. Wajib pajak tau cara menghitung jumlah pajak yang akan dikenakan pada penghasilan yang diterimanya.

4. Wajib pajak menghitung sendiri pajak terutangnya, artinya wajib pajak melakukan perhitungan sendiri secara mandiri tentang seberapa besar pajak terutang yang harus dia bayar.

5. Wajib pajak membayar sendiri pajak terutangnya, artinya wajib pajak melakukan pembayaran secara mandiri pajak terutangnya.
6. Wajib pajak melaporkan sendiri SPT dan pajak terutangnya.

7. Peran fiskus (pemerintah) dalam proses implementasi self assessment system, baik dalam proses edukasi masyarakat melalui sosialisasi maupun dalam penyelenggaraan pelayanan.

8. Pemantauan oleh Fiskus, artinya peran fiskus (pemerintah) dalam proses penerapan self assessment system juga melakukan pemantauan untuk melihat perkembangan serta membantu apabila wajib pajak mengalami kesulitan dalam penerapan self assessment system.

9. Fiskus membatu wajib pajak yang kesulitan dalam mempratikan sistem Self Assessment System.

\section{Kerangka Pemikiran}

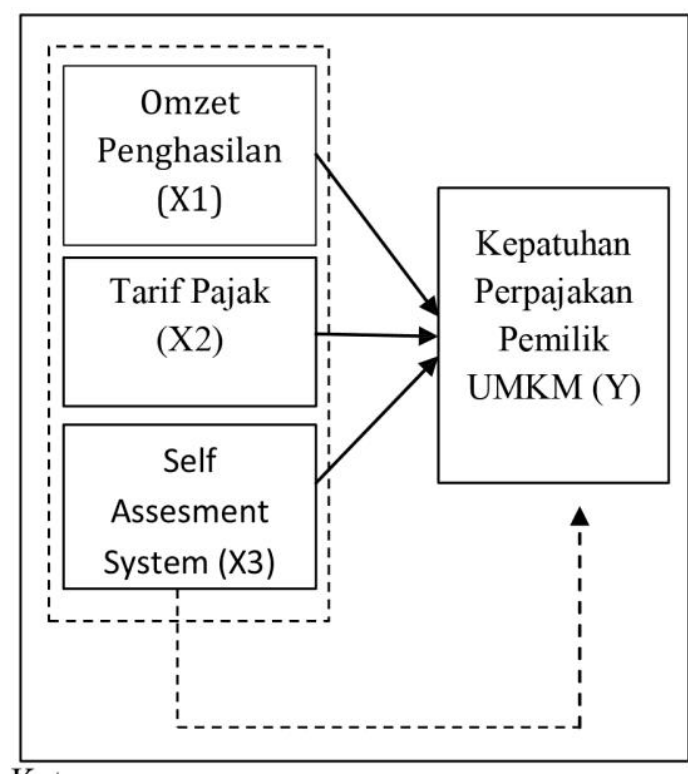

Gambar 1 Kerangka Pemikiran

Keterangan:

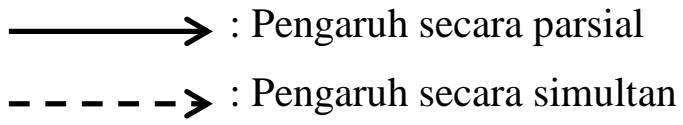




\section{Perumusan Hipotesis}

Kuncoro (2009; 61) menyatakan hipotesis adalah suatu penjelasan sementara tentang perilaku, fenomena, atau keadaan tertentu yang telah terjadi atau akan terjadi.

Hipotesis merupakan pernyataan peneliti tentang hubungan antara variabelvariabel dalam penelitian, dan merupakan pernyataan yang paling spesifik.

Berdasarkan beberapa penjelasan teori di atas maka diperoleh hipotesis penelitian sebagai berikut:

H1. Diduga terdapat pengaruh secara simultan dari omzet penghasilan, tariff pajak, self assessment system secara simultan terhadap kepatuhan wajib pajak UMKM di Kota Tegal.

H2. Diduga terdapat pengaruh secara parsial dari omzet penghasilan terhadap kepatuhan wajib pajak UMKM di Kota Tegal

H3. Diduga terdapat pengaruh secara parsial dari tarif pajak terhadap kepatuhan wajib pajak UMKM di Kota Tegal.

H4. Diduga terdapat pengaruh secara parsial dari self assessment system terhadap kepatuhan wajib pajak di Kota Tegal.

\section{METODOLOGI PENELITIAN}

\section{Desain Penelitian}

Penelitian ini adalah penelitian deskriptif dengan pendekatan kuantitatif. Metode penelitian kuantitatif menurut Sugiyono (2012; 23) adalah metode penelitian yang berlandaskan pada filsafat positivism, digunakan untuk meneliti pada populasi atau sampel tertentu, pengumpulan data menggunakan instrument penelitian, analisis data bersifat kuantitatif/statistic, dengan tujuan untuk menguji hipotesis yang telah ditetapkan. Penelitian ini dilakukan dengan cara terjun langsung ke lapangan untuk memperoleh data yang diperlukan dalam penelitian. Penelitian ini menggunakan kuesioner dalam memperoleh datanya. Kuesioner tersebut akan dibagikan ke beberapa UMKM yang menjadi sampel dalam penelitian ini. Perhitungan serta alat pengujian dalam penelitian ini menggunakan SPSS.

\section{Lokasi Penelitian}

Penelitian ini dilakukan berdasarkan lokasi dari objek yang akan diteliti yaitu wajib pajak UMKM yang terdaftar di KPP Pratama Kota Tegal. Beralamatkan di J1. Kol. Sugiono No.5 Tegal. Penelitian ini merupakan jenis penellitian lapangan. Penelitian lapangan memudahkan peneliti untuk memperoleh informasi dan data terbaru sedekat mungkin dengan objek yang akan diteliti.

\section{Populasi dan Sampel}

Kuncoro (2009; 118) menyatakan populasi adalah kelompok elemen yang lengkap, yang biasanya berupa orang, objek, transaksi, atau kejadian di mana kita tertarik untuk mempelajarinya atau menjadi objek penelitian. Berdasarkan hal tersebut maka populasi atau objek yang menjadi fokus dalam penelitian ini adalah seluruh jumlah Usaha Mikro, Kecil, dan Menengah yang berada pada di Kota Tegal yaitu sebanyak 660 UMKM. Sampel adalah suatu hal yang dapat mewakili suatu populasi dan merupakan bagian dari populasi. Teknik pengambilan sampel dalam penelitian ini menggunakan metode Probability Sampling dengan metode Simple Random yang dipilih, dalam menentukan jumlah sampel menggunakan Rumus 
Slovin dan menghasilkan sebanyak 87 sampel.

\section{Jenis data}

Jenis data dalam penelitian ini adalah data primer. Menurut Kuncoro (2009; 157), data primer adalah data yang dikumpulkan dari sumber-sumber asli dengan tujuan tertentu. Dalam penelitian ini tujuan dari pengumpulan data adalah untuk memperoleh informasi langsung yang bersumber dari responden. data primer dalam penelitian ini adalah berupa kuesioner.

\section{Sumber Data}

Sumber data yang digunakan dalam penelitian ini adalah kuesioner yang telah dijawab oleh para responden, adapun responden dalam penelitian ini adalah wajib pajak Usaha Mikro, Kecil, dan Menengah (UMKM) yang terdaftar di Kantor Pelayanan Pajak Pratama Tegal.

\section{HASIL DAN PEMBAHASAN}

\section{Sejarah KPP Pratama Tegal}

Pada bulan Juni tahun 1964 pemerintah mendirikan Kantor Inspeksi Keuangan Pekalongan yang di resmikan oleh DPJ Drs. Soejono Brotodiharjo. Dengan wilayah kerja dari Kantor Inspeksi Keuangan Pekalongan meliputi wilayah Karesidenan Pekalongan termasuk Kabupaten Tegal dan Brebes, sementara untuk Kota Madya Tegal pada saat itu belum terbentuk.

Melalui Kantor Dinas Luar (KDL) Tingkat I Tegal, usaha untuk menggali potensi pajak terus dgalakkan seiring dengan perkembangan perekonomian di kedua daerah tersebut Kabupaten Tegal baik pada saat itu hingga sekarang. Tegal tidak saja terkenal dengan produksi gula tebu, tetapi juga terkenal dengan daerah penghasil ikan dan sekarang ini dikembangkan pertanian bawang putih yang berlokasi di sekitar daerah Gunung Slamet, sedangkan untuk daerah Kabupaten Brebes yang memiliki areal bawang merah dan cabai merah yang luas mampu memproduksi kedua komoditi tersebut dalam jumlah yang besar. Bahkan produksi bawang merah dan cabai merah merupakan stok nasional untuk komoditi tersebut. Karena adanya kondisi yang memungkinkan untuk berkembang, seiring dengan peningkatan potensi ekonomi masyarakat, maka Dirjen Pajak mempertimbangkan agar Kantor Dinas Luar (KDL) menjadi Kantor Inspeksi Tegal.

Nama Kantor Inspeksi Pajak Tegal kemudian diubah menjadi Kantor Pelayanan Pajak (KPP) pada tahun 1989 sesuai dengan kebijakan yang ditetapkan oleh Dirjen Pajak, dalam Keputusan Menteri Keuangan Republik Indonesia Nomor 276/KMK/01/1989 tanggal 25 Maret 1989 tentang Organisasi dan Tata Kerja Dirjen Pajak, diatur tentang perubahan penanaman dari Kantor Inspeksi Pajak menjadi Kantor Pelayanan Pajak, dengan didasari bahwa dewasa ini tugas Dirjen Pajak tidak hanya melakukan inspeksi atau pemeriksaan semata tetapi juga mengutamakan pelayanan administrasi pajak kepada masyarakat luas terutama wajib pajak.

Kemudian nama Kantor Pelayanan Pajak (KPP) Tegal berubah menjadi Kantor Pelayanan Pajak (KPP) Pratama Tegal dengan menerapkan sistem administrasi perpajakan modern pada tahun 2008 berdasarkan Peraturan Menteri Keuangan Republik Indonesia Nomor : 67/PMK.01/2008 tanggal 6 Mei 2008 tentang "Perubahan Kedua atas Peraturan Menteri Keuangan Nomor 132/PMK.01/2006 tentang Organisasi dan Tata Kerja Instansi Vertikal 
Direktorat Jenderal Pajak", dengan Kepala Kantor sebagai berikut:
a. Drs. Moh. I. Budhy Triwindhu
b. Drs. Suwarno, MBA
c. Adilega Tanius
d. Jhony Victor
e. Budi Gunawan

\section{Visi, Misi dan Motto}

a. Visi

Menjadikan Kantor Pelayanan Pajak (KPP) handal, inovatif dan akuntabel dalam melayani wajib pajak.

b. Misi

Melayani wajib pajak secara optimal untuk mewujudkan wajib pajak yang sadar dan patuh pajak.

c. Motto

Melayani dengan PRIMA, Profesional, Ramah, Integritas, Mudah dan Akurat.

\section{Gambaran Umum Responden}

Penelitian ini dilaksanakan di Kota Tegal pada bulan Juni-Juli 2018. Responden dalam penelitian ini adalah UMKM yang terdapat di Kota Tegal yang memiliki peredaran bruto kurang dari atau sama dengan Rp 4,8 miliar. Peneli menyebar sebanyak 90 kuesioner dan kuesioner yang memenuhi syarat data sampel sebanyak 83 kuesioner. Respon rate sebesar 92,22\%.

\section{Hasil Uji Instrumen}

\section{Uji Validitas}

Dalam hal ini peneliti mengukur tingkat kevalidan kuesioner kepatuhan wajib pajak yang berjumlah 9 butir item pernyataan. Setiap item butir pernyataan akan diuji tingkat validitasnya menggunakan SPSS yang memberikan hasil yang terdapat pada lampiran.
Tabel 2 Hasil Uji Validitas

\begin{tabular}{|c|c|c|c|c|}
\hline Variabel & Pertanyaan & $\begin{array}{c}c- \\
\text { Hitung }\end{array}$ & $\begin{array}{c}\mathrm{r}- \\
\text { Tabel }\end{array}$ & Keterangan \\
\hline \multirow{9}{*}{$\begin{array}{l}\text { Kepatuhan } \\
\text { Wajib Pajak } \\
\text { UMKM (Y) }\end{array}$} & 1 & 0,2159 & 0,679 & Valid \\
\hline & 2 & 0,2159 & 0,540 & Valid \\
\hline & 3 & 0,2159 & 0,605 & Valid \\
\hline & 4 & 0,2159 & 0,622 & Valid \\
\hline & 5 & 0,2159 & 0,725 & Valid \\
\hline & 6 & 0,2159 & 0,658 & Valid \\
\hline & 7 & 0,2159 & 0,727 & Valid \\
\hline & 8 & 0,2159 & 0,547 & Valid \\
\hline & 9 & 0,2159 & 0,492 & Valid \\
\hline \multirow{9}{*}{$\begin{array}{l}\text { Omzet } \\
\text { Penghasilan } \\
\text { (X1) }\end{array}$} & 1 & 0,2159 & 0,631 & Valid \\
\hline & 2 & 0,2159 & 0,332 & Valid \\
\hline & 3 & 0,2159 & 0,307 & Valid \\
\hline & 4 & 0,2159 & 0,747 & Valid \\
\hline & 5 & 0,2159 & 0,722 & Valid \\
\hline & 6 & 0,2159 & 0,554 & Valid \\
\hline & 7 & 0,2159 & 0,611 & Valid \\
\hline & 8 & 0,2159 & 0,663 & Valid \\
\hline & 9 & 0,2159 & 0,445 & Valid \\
\hline \multirow{5}{*}{$\begin{array}{c}\text { Tarif Pajak } \\
\text { (X2) }\end{array}$} & 1 & 0,2159 & 0,485 & Valid \\
\hline & 2 & 0,2159 & 0,711 & Valid \\
\hline & 3 & 0,2159 & 0,630 & Valid \\
\hline & 4 & 0,2159 & 0,632 & Valid \\
\hline & 5 & 0,2159 & 0,550 & Valid \\
\hline \multirow{9}{*}{$\begin{array}{c}\text { Self } \\
\text { Assesment } \\
\text { System (X3) }\end{array}$} & 1 & 0,2159 & 0,675 & Valid \\
\hline & 2 & 0,2159 & 0,618 & Valid \\
\hline & 3 & 0,2159 & 0,675 & Valid \\
\hline & 4 & 0,2159 & 0,736 & Valid \\
\hline & 5 & 0,2159 & 0,723 & Valid \\
\hline & 6 & 0,2159 & 0,704 & Valid \\
\hline & 7 & 0,2159 & 0,666 & Valid \\
\hline & 8 & 0,2159 & 0,674 & Valid \\
\hline & 9 & 0,2159 & 0,773 & Valid \\
\hline
\end{tabular}

Sumber: Data diolah SPSS 22

Berdasarkan data yang sudah diolah, nilai $\mathrm{r}$ tabel dengan $\mathrm{n}=87$ dan pada sigifikansi 0,5 adalah sebesar 0,2159, maka dapat disimpulkan bahwa hubungan antara pertanyaan dari variabel $\mathrm{X}_{1}, \mathrm{X}_{2}, \mathrm{X}_{3}$ dan $\mathrm{Y}$, adalah valid, karena semua hubungan pertanyaan lebih dari 0,2159 .

\section{Uji Reliabilitas}

Reliabilitas adalah suatu pengujian instrument untuk memperoleh tingkat ketepatan instrument yang digunakan sebagai dasar pengambilan keputusan yang terdiri dari beberapa item butir penyataan akan dapat dipercaya apabila nilai cronbach Alpha di atas 0,07 . 
Tabel 3

Uji Reliabilitas Instrumen

\begin{tabular}{|l|l|l|l|}
\hline Variabel & R hitung & $\begin{array}{l}\text { Cronbach } \\
\text { Alpha }\end{array}$ & Keterangan \\
\hline $\begin{array}{l}\text { Kepatuhan } \\
\text { Wajib Pajak } \\
\text { (Y) }\end{array}$ & 0,753 & 0,07 & Reliabel \\
\hline $\begin{array}{l}\text { Omzet } \\
\text { Penghasilan } \\
\text { (X1) }\end{array}$ & 0,735 & 0,07 & Reliabel \\
\hline $\begin{array}{l}\text { Tarif Paja } \\
\text { (X2) }\end{array}$ & 0,732 & 0,07 & Reliabel \\
\hline $\begin{array}{l}\text { Self } \\
\text { Assessment } \\
\text { System (X3) }\end{array}$ & 0,769 & 0,07 & Reliabel \\
\hline
\end{tabular}

Sumber: Data primer yang diolah 2018

Berdasarkan hasil perhitungan reliabilitas instrument variabel kepatuhan wajib pajak UMKM (Y) diperoleh nilai reliabilitas sebesar 0,753 , reliabilitas instrument variabel omzet penghasilan (X1) diperoleh nilai reliabilitas sebesar 0,735 , reliabilitas instrument tarif pajak (X2) diperoleh nilai reliabilitas sebesar 0,732, dan reliabilitas instrument self assessment system (X3) diperoleh nilai reliabilitas sebesar 0,769. Kuesioner dapat dikatakan reliable apabila nilai $\alpha>$ 0,07, dan dari hasil penelitian menyatakan nilai Cronbach alpha variabel > 0,07 maka kuesioner tersebut dikatakan reliable. Dengan demikian instrument variabel kepatuhan wajib pajak UMKM, omzet penghasilan, tarif pajak, self assessment system dapat dikatakan reliable.

\section{Analisis Regresi Linier Berganda}

Analisis regresi merupakan hubungan secara linier dua atau lebih variabel independen $(\mathrm{X} 1, \mathrm{X} 2, \ldots, \mathrm{Xn})$ dengan variabel dependen (Y), dengan tujuan untuk memprediksi rata-rata populasi atau nilai rata- rata variabel dependen berdasarkan nilai variabel independen yang diketahui.
Tabel 4

Uji Regresi Linier Berganda

\begin{tabular}{|c|c|c|c|c|}
\hline & $\begin{array}{l}\text { Unstandardized } \\
\text { Coefficients }\end{array}$ & $\begin{array}{l}\text { Standardized } \\
\text { Coefficients }\end{array}$ & & \\
\hline $\begin{array}{l}\text { Model } \\
\text { (Constant) }\end{array}$ & \begin{tabular}{|c|l} 
B & Std. Error \\
9,444 & 3,319
\end{tabular} & Beta & \begin{tabular}{|c}
$\mathbf{T}$ \\
2,846
\end{tabular} & $\begin{array}{l}\text { Sig. } \\
006\end{array}$ \\
\hline $\begin{array}{l}\text { Omzet } \\
\text { Penghasilan }\end{array}$ & $712 \mid .106$ & 630 & & 000 \\
\hline Tarif Pajak & $-, 343 \quad, 160$ & -184 & 2,148 & 035 \\
\hline $\begin{array}{l}\text { Self Assessment } \\
\text { System }\end{array}$ & $.204 \quad 078$ & .230 & 2,608 & .011 \\
\hline
\end{tabular}

Sumber: Olah data SPSS, 2018

Berdasarkan tabel di atas, dapat dilihat nilai konstanta sebesar 9,444, omzet penghasilan sebesar 0,712, tarif pajak sebesar $-0,343$ dan self assessment system sebesar 0,204 sehingga diperoleh persamaan regressi yaitu:

$\mathrm{Y}=9,444+0,712+-0.343+0,204+\mathrm{e}$

Berdasarkan persamaan regresi berganda tersebut dapat diambil analisis sebagai berikut:

a. Nilai konstanta sebesar 9,444 (Y) berarti menunjukkan jika omzet penghasilan, tarif pajak, dan self assessment system adalah 9,444 maka peningkatan kepatuhan wajib pajak UMKM akan tetap sebesar 9,444.

b. Nilai koefisien X1 sebesar 0,712 artinya apabila terdapat peningkatan variabel omzet penghasilan sebesar 1 satuan sementara variabel independen lainnya tetap, maka kepatuhan wajib pajak UMKM (Y) akan mengalami peningkatan sebesar 0,712 .

c. Nilai koefisien X2 sebesar $-0,343$ artinya apabila terdapat penurunan variabel tarif pajak sebesar 1 satuan sementara variabel independen lainnya tetap, maka kepatuhan wajib pajak UMKM (Y) akan mengalami penurunan sebesar 0,343.

d. Nilai koefisien X3 sebesar 0,204 artinya apabila terdapat peningkatan variabel self assessment system 
sebesar 1 satuan sementara variabel independen lainnya tetap, maka kepatuhan wajib pajak UMKM (Y) akan mengalami penurunan sebesar 0,204 .

\section{Pengujian Hipotesis}

\section{a. Uji Simultan}

Uji simultan digunakan untuk mengetahui apakah seluruh variabel independen secara bersama-sama mempunyai pengaruh yang bermakna terhadap variabel dependen.

\section{Tabel 5}

\section{Uji Simultan/Uji F}

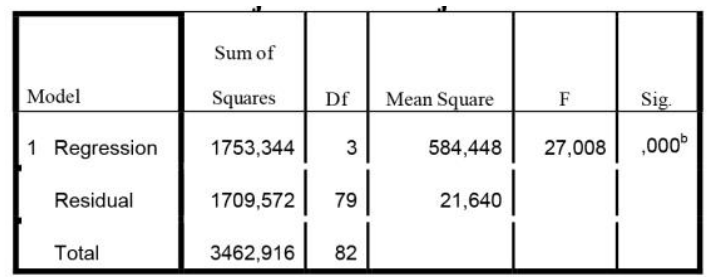

Berdasarkan hasil uji $\mathrm{F}$ diperoleh nilai uji $F$ sebesar 27,008 dengan signifikansi yaitu sebesar $0,000<0,05$ maka dapat diperoleh suatu kesimpulan bahwa hipotesis pertama yaitu "diduga omzet penghasilan, tarif pajak, serta self assessment system secara bersama- sama berpengaruh terhadap kepatuhan wajib pajak UMKM di Kota Tegal"dapat diterima kebenarannya.

\section{b. Uji Parsial}

Uji parsial digunakan untuk mengetahui apakah masing-masing variabel independen terdapat pengaruh terhadap variabel dependen pada model regresi.
Tabel 6

Uji Parsial/ Uji t

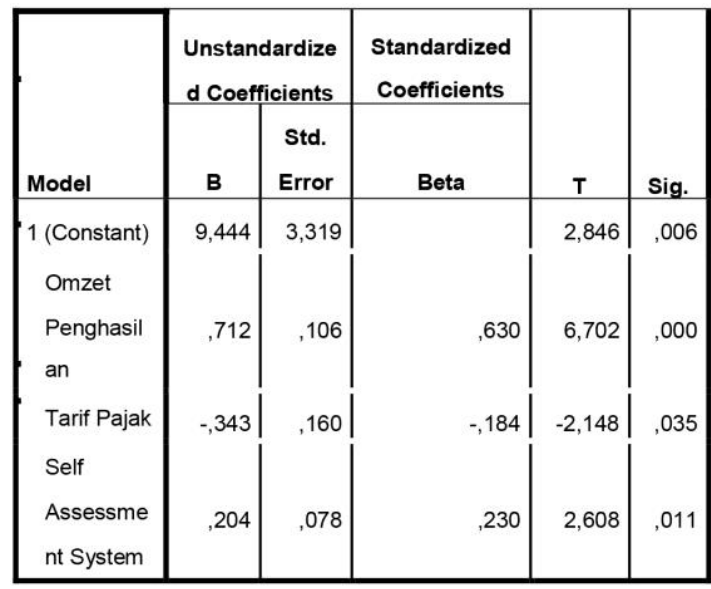

Berdasarkan tabel di atas dapat diperoleh penjelasan sebagai berikut:

1. Varibel omzet penghasilan berpengaruh terhadap kepatuhan wajib pajak UMKM di Kota Tegal. Dari perhitungan uji $t$ dengan menggunakan SPSS diperoleh nilai $\mathrm{t}$ hitung sebesar 6,702 dan sig $=0,000$ $<0,05$ sehingga dapat disimpulkan bahwa omzet penghasilan (X1) berpengaruh terhadap kepatuhan wajib pajak UMKM di Kota Tegal, dengan demikian hipotesis kedua yaitu "diduga omzet penghasilan berpengaruh terhadap kepatuhan wajib pajak UMKM di Kota Tegal" dapat diterima kebenarannya.

2. Variabel tarif pajak berpengaruh terhadap kepatuhan wajib pajak UMKM di Kota Tegal. Dari perhitungan uji $t$ dengan menggunakan SPSS diperoleh nilai $\mathrm{t}$ hitung sebesar $-2,148$ dan sig $=0,035$ $<0,05$ sehingga dapat disimpulkan bahwa tarif pajak berpengaruh terhadap kepatuhan wajib pajak UMKM di Kota Tegal, dengan demikian hipotesis ke tiga yaitu "diduga tarif pajak berpengaruh terhadap kepatuhan wajib pajak UMKM ke Kota Tegal" dapat diterima kebenarannya. 
3. Variabel self assessment system berpengaruh terhadap kepatuhan wajib pajak UMKM di Kota Tegal. Dari perhitungan uji $t$ dengan menggunakan SPSS diperoleh nilai $t$ hitung sebesar 2,608 dan Sig $=0,011$ $<0,05$ sehingga dapat disimpulkan bahwa self assessment system berpengaruh terhadap kepatuhan wajib pajak UMKM di Kota Tegal, dengan demikian hipotesis ke empat yaitu "diduga self assessment system berpengaruh terhadap kepatuhan wajib pajak UMKM di Kota Tegal" dapat diterima kebenarannya.

\section{Pembahasan}

Berdasarkan hasil pengujian hipotesis menggunakan SPSS versi 22 memberikan hasil hipotesis baik secara simultan maupun parsial. Pada pengujian ini diperoleh hasil bahwa variabel independen yang terdiri dari omzet penghasilan, tarif pajak, serta self assessment system secara bersama-sama mempengaruhi variabel dependen yaitu kepatuhan wajib pajak UMKM di Kota Tegal dengan nilai signifikansi $0,000<$ 0,05 . Sehubungan dengan hal tersebut maka dapat disimpulkan diterima. Pengujian secara parsial antara variabel independen omzet penghasilan, tarif pajak, serta self assessment system dengan variabel dependen kepatuhan wajib pajak UMKM di Kota Tegal diperoleh sebagai berikut:

1. Pengaruh omzet penghasilan terhadap kepatuhan wajib pajak UMKM di Kota Tegal

Berdasarkan hasil pengujian hipotesis secara parsial dengan menggunakan SPSS pada penelitian ini diperoleh nilai $\mathrm{t}$ hitung sebesar 6,702 dan nilai sinifikansi dari variabel omzet penghasilan yaitu sebesar 0,000 lebih kecil dari 0,05 $(0,000<0,05)$. Hal ini berarti menunjukkan bahwa omzet penghasilan berpengaruh terhadap kepatuhan wajib pajak UMKM di Kota Tegal, sehingga dapat disimpulkan bahwa dalam penelitian ini diterima.

Hasil penelitian ini didukung oleh teori atribusi, menurut Robbins dan Judge (2008) dalam Megantara, dkk (2017) teori atribusi merupakan suatu teori yang menjelaskan bahwa individu melakukan pengamatan terhadap perilaku yang dilakukan seseorang, bahwa seseorang dalam melakukan suatu tindakkan mereka akan mempertimbangkan berdasarkan faktor internal maupun eksternal. Pertimbangan secara internal adalah perilaku yang diyakini berada di bawah kendali pribadi individu itu sendiri atau berasal dari faktor internal seperti ciri kepribadian, kesadaran, dan kemampuan.

Omzet penghasilan dalam penelitian ini berpengaruh terhadap kepatuhan wajib pajak UMKM di Kota Tegal, hal ini dikarenakan berdasarkan survei yang peneliti lakukan, kebanyakan wajib pajak merasa lebih mudah dan lebih sadar untuk membayar pajak ketika omzet mereka tinggi atau ketika memang omzet mereka sudah mencapai kriteria yang harus dikenakan pajak oleh pemerintah maka mereka akan cenderung lebih mudah dan lebih patuh untuk membayar pajak, dibandingkan ketika mereka memiliki omzet yang rendah, kebanyakan wajib pajak UMKM merasa keberatan khususnya mereka yang masih dalam kategori mikro, apabila dikenakan pajak atas omzet yang tidak seberapa (rendah) yang mereka terima maka mereka akan cenderung menolak atau tidak mau membayar pajak. 
Kebenaran atas hasil penelitian ini diperkuat dengan hasil penelitian dari Megantara, dkk (2017) menyatakan variabel penghasilan wajib pajak berpengaruh secara positif dan signifikan terhadap kepatuhan wajib pajak usahawan atas penerapan Peraturan Pemerintah Nomor 46 Tahun 2013. Dan juga penelitian dari Arviana dan Sadjiarto (2014), dan Rizajayanti (2017), yang menyatakan bahwa omzet penghasilan berpengaruh terhadap kepatuhan wajib pajak, dan dalam penelitian ini omzet penghasilan juga berpengaruh terhadap kepatuhan wajib pajak UMKM.

2. Pengaruh tarif pajak terhadap kepatuhan wajib pajak UMKM di Kota Tegal

Berdasarkan hasil pengujian hipotesis secara parsial dengan menggunakan SPSS pada penelitian ini diperoleh nilai signifikansi dari variabel tarif pajak sebesar 0,035 lebih kecil dari $0,05(0,035<0,05)$ dengan $\mathrm{t}$ hitung sebesar $-2,148$. Hal ini berarti menunjukkan bahwa tarif pajak berpengaruh terhadap kepatuhan wajib pajak UMKM di Kota Tegal, sehingga dapat disimpulkan bahwa dalam penelitian ini diterima.

Hasil penelitian di atas didukung dengan teori yang ada yaitu kepatuhan adalah suatu tindakan seseorang dalam melaksanakan suatu peraturan atau asas yang berlaku sesuai dengan peraturan yang ada. Menurut Nurmantu (2003) dalam Widodo, dkk (2010; 66) kepatuhan merupakan suatu keadaan di mana wajib pajak melaksanakan serta memenuhi semua hak dan kewajiban perpajakannya. Tarif pajak merupakan salah satu contoh peraturan dalam bidang perpajakan. Sudirman dan Amirudin menyatakan tarif pajak adalah ketentuan persentase $(\%)$ atau jumlah (rupiah) pajak yang harus dibayar oleh wajib pajak sesuai dengan dasar pajak atau objek pajak. semakin baik dan tepat peraturan yang berlaku maka akan semakin baik pula wajib pajak dalam membayar pajaknya. (Sudirman dan Amirudin, 2012; 9 dalam Ananda dkk, 2015).

Dalam penelitian ini tarif pajak berpengaruh terhadap kepatuhan wajib pajak, hal tersebut dikarenakan bagi kebanyakan UMKM tarif $\mathrm{PPh}$ final yang saat ini berlaku adalah salah satu pertimbangan mereka dalam membayar pajak, dari survei yang dilakukan peneliti, tarif sebesar $1 \%$ untuk seluruh lapisan UMKM dirasa tidak cukup adil, maka perlu bagi pemerintah untuk mengkaji ulang mengenai tarif pajak, agar dapat sesuai dengan kemampuan setiap lapisan wajib pajak UMKM guna meningkatkan kepatuhan wajib pajak UMKM dalam membayar pajak. Hal tersebut diperjelas berdasarkan survei lapangan yang dilakukan oleh peneliti hal tersebut dapat terjadi karena sebagian besar UMKM mengatakan apabila tarif yang saat ini berlaku sudah adil bagi setiap lapisan UMKM maka mereka akan cenderung lebih patuh dalam membayar pajak. Dengan hal tersebut dapat disimpulkan bahwa semakin adil dan semakin tepat tarif pajak yang berlaku akan semakin meningkatkan kepatuhan wajib pajak UMKM dalam membayar pajak. Tarif pajak akan menjadi pengaruh yang negatif apabila tarif yang di kenaikan kepada wajib pajak tidak sesuai dengan kemampuan setiap lapisan UMKM maka hal tersebut dapat menurunkan kepatuhan wajib 
pajak UMKM di Kota Tegal dalam membayar pajak.

3. Pengaruh self assessment system terhadap kepatuhan wajib pajak UMKM di Kota Tegal

Berdasarkan hasil pengujian hipotesis secara parsial dengan menggunakan SPSS pada penelitian ini diperoleh nilai $t$ hitung sebesar 2,608 dan nilai signifikansi dari variabel self assessment system sebesar 0,011 lebih kecil dari 0,05 $(0,011<0,05)$. Hal ini berarti menunjukkan bahwa self assessment system berpengaruh terhadap kepatuhan wajib pajak UMKM di Kota Tegal, sehingga dapat disimpulkan bahwa dalam penelitian ini diterima.

Self assessment system dalam penelitian ini ditemukan dapat mempengaruhi kepatuhan wajib pajak UMKM di Kota Tegal. Hal tersebut didukung dengan teori yang ada yaitu menurut Maharani (2015) sistem self assessment system di Indonesia dapat menunjang besarnya peranan wajib pajak dalam menentukan besarnya penerimaan pajak bagi negara dari sektor pajak yang didukung oleh kepatuhan pajak. Kepatuhan wajib pajak merupakan suatu ketaatan wajib pajak dalam menghitung dan melaporkan pajak terutangnya dengan benar sesuai dengan teori yang ada menurut Mardiasmo (2016; 9) mengatakan self assessment system adalah suatu sistem pemungutan pajak di mana wewenang sepenuhnya diberikan kepada wajib pajak untuk menentukan sendiri besarnya pajak terutangnya memiliki ciri-ciri yaitu wewenang untuk menentukan besarnya pajak terutang ada pada wajib pajak, wajib pajak aktif, yaitu wajib pajak melakukan perhitungan, menyetor, dan melaporkan sendiri pajak terutangnya, fiskus berperan hanya mengawasi tidak ikut campur dalam hal apapun.

Berdasarkan hasil dari penelitian survei lapangan yang dilakukan oleh peneliti. Peneliti menemukan bahwa tata cara perpajakan yaitu self assessment system sangat mempengaruhi kepatuhan wajib pajak UMKM, baik UMKM yang memiliki NPWP maupun yang belum memiliki NPWP, sebagian besar UMKM yang memiliki NPWP berpendapat bahwa mereka jauh lebih percaya untuk membayar pajak, krisis kepercayaan mereka berkurang akibat banyaknya isu- isu mengenai penyalahgunaan uang pajak yang mereka bayar membuat mereka sedikit kehilangan kepercayaan untuk membayar pajak, dengan adanya penerapan self assessment system mereka menjadi lebih berani dan bertanggung jawab karena besarnya pajak yang mereka bayarkan adalah atas perhitungan dan pengelolaan yang mereka lakukan sendiri serta peran pemerintah yang senantiasa membantu pada setiap ketidak pahaman para UMKM membuat mereka semakin

\section{E. KESIMPULAN DAN SARAN}

\section{Kesimpulan}

Berdasarkan uraian pada hasil penelitian dan pembahasan bab-bab sebelumnya maka dapat diambil kesimpulan sebagai berikut:

1. Omzet penghasilan berpengaruh terhadap kepatuhan wajib pajak UMKM hal tersebut didukung dengan hasil pengujian hipotesis secara parsial diperoleh nilai sinifikansi dari variabel omzet 
penghasilan yaitu sebesar 0,000 lebih kecil dari $0,05(0,000<0,05)$.

2. Tarif pajak berpengaruh terhadap kepatuhan wajib pajak UMKM hal tersebut didukung dengan hasil pengujian hipotesis secara parsial diperoleh nilai signifikansi dari variabel tarif pajak sebesar 0,035 lebih kecil dari $0,05(0,035<0,05)$ dengan t hitung sebesar $-2,148$.

3. Self assessment system berpengaruh terhadap kepatuhan wajib pajak UMKM hal tersebut didukung dengan hasil pengujian hipotesis secara parsial diperoleh nilai signifikansi dari variabel self assessment system sebesar 0,011 lebih kecil dari $0,05(0,011<0,05)$.

4. Omzet penghasilan, tarif pajak, serta self assessment system secara bersama-sama berpengaruh terhadap variabel dependen yaitu kepatuhan wajib pajak UMKM di Kota Tegal. Hal tersebut didukung dengan hasil nilai Adjusted $\mathrm{R}$ Square sebesar 0,488 atau $48,8 \%$ nilai tersebut menunjukkan besarnya kontribusi pengaruh omzet penghasilan, tarif pajak, serta self assessment system terhadap kepatuhan wajib pajak UMKM di Kota Tegal. Adapun sisanya sebesar $51,2 \%$ dipengaruhi oleh variabel lain yang tidak dijelaskan dalam penelitian ini.

\section{Saran}

Berdasarkan kesimpulan yang sudah dijabarkan di atas, maka peneliti memberikan saran sebagai berikut:

1. Dari hasil pengujian disimpulkan bahwa omzet penghasilan mempengaruhi kepatuhan wajib pajak UMKM. Pemerintah diharapkan dapat memberikan edukasi dan sosialisi tentang bagaimana caranya agar UMKM dapat memasarkan produk mereka lebih baik lagi sehingga meningkatkan minat pembeli terhadap produk yang dijual oleh UMKM sehingga dapat meningkatkan omzet bagi mereka dan meningkatkan kepatuhan para pelaku UMKM dalam membayar pajak.

2. Dari hasil pengujian disimpulkan bahwa tarif pajak berpengaruh terhadap kepatuhan wajib pajak UMKM. Diharapkan Kementrian Keuangan dan Direktorat Jendral Pajak dapat meninjau kembali kemampuan para UMKM dan menyesuaikan tarif pajak agar sesuai dengan kemampuan para UMKM dan tidak memberatkan mereka. Sehingga UMKM akan lebih patuh dalam membayar pajak.

3. Dari hasil pengujian disimpulkan bahwa self assessment system berpengaruh terhadap kepatuhan wajib pajak UMKM. Diharapkan Pemerintah dapat memberikan banyak edukasi dan sosialisasi tentang penerapan tata cara perpajakan dan lebih mempermudah lagi tatacara perpajakannya, khususnya pada bagian perhitungan perpajakan, banyak sekali UMKM yang masih belum paham mengenai cara menghitung sendiri pajak mereka.

4. Bagi peneliti selanjutnya diharapkan untuk memperluas sampel penelitian tidak hanya di wilayah Kota namun juga merambah ke Kabupaten atau menambah kota yang lainnya yang lebih besar. Diharapkan peneliti selanjutnya juga memperluas variabel independen penelitian karena dari hasil penelitian masih terdapat 51,2\% dipengaruhi oleh variabel lain yang tidak dijelaskan dalam penelitian ini seperti variabel pengetahuan, kesadaran serta tingkat pendidikan pemilik UMKM. 
5. Bagi para pelaku UMKM Omzet merupakan suatu yang mempengaruhi kepatuhan wajib pajak UMKM sehingga diharapkan para UMKM melaporkan omzet penghasilan dengan sebenar-benarnya serta bertanggung jawab atas kewajiban perpajakan setiap masing masing usaha agar pemerintah dapat mempertimbangkan tarif serta tata cara yang sesuai dengan kemampuan para UMKM dan tidak memberatkan mereka.

\section{DAFTAR PUSTAKA}

Abidin, Nurfaizah (2016). Pengaruh tarif pajak, sistem perpajakan, pengawasan Pajak dan sunset policy terhadap minimalisasi tax Evasion (penggelapan pajak) (studi empiris pada wajib pajak di kpp pratama wilayah makassar selatan). Skripsi.Universitas Islam Negeri Alauddin Makasar.

Anggara, Aditya, dan Sulistiyanti, Umi (2017). Kepatuhan Pajak Usaha Mikro, Kecil, dan Menengah di Surakarta. Simposium Nasional Akuntansi XX Jember.

Arikunto, Suharsimi (2013). Prosedur Penelitian Suatu Pendekatan Praktek. Jakarta: Rineka Cipta

Arviana, Nerissa, dan Sadjiarto, Arja (2014). Pengaruh Pemahaman Peraturan, Omset, Pemeriksaan, Sanksi, Relasi Sosial, dan Persaingan Usaha Terhadap Kepatuhan Wajib Pajak Restoran di Mojokerto Tahun 2014. Jurnal Tax \& Accounting Review, Vol.4 No. 1. BI, LPPI (2015). Profil Bisnis Usaha Mikro Kecil dan Menengah (UMKM) Jakarta: Bank Indonesia

Chaerunnisa. (2010). Analisis pengaruh tingkat penghasilan dan Sanksi pajak terhadap kepatuhan wajib pajak dalam menyampaikan SPT tahunan untuk wwajib pajak orang pribadi di wilayah kembangan jawa barat. Skripsi. Universitas Islam Negeri Syarifhidyatulloh. Jakarta

Dwi Ananda, Pasca Rizki, dkk. (2015). Pengaruh Sosialisasi Perpajakan, Tarif Pajak, dan Pemahaman Perpajakan Terhadap Kepatuhan Wajib Pajak (Studi Pada UMKM Yang Terdaftar Sebagai Wajib Pajak di Kantor Pelayanan Pajak Pratama Batu). Jurnal Perpajakan, Vol.6 No.2.

Fatmawati. (2015). Pengaruh Pemahaman Wajib Pajak Atas PP no.46 Tahun 2013 dan Implementasi Self Assessment System Terhadap Kepatuhan Wajib Pajak dengan Persepsi Wajib Pajak Sebagai Variabel Moderasi (Studi Empiris Pada Pelaku UMKM Kerajinan Gerabah Kasongan). Skripsi Program Sarjana, Universitas Negeri Yogyakarta.

Ghozali, Imam (2011). Aplikasi Analisis Multivariate dengan Program IBM SPSS19. Semarang: UNDIP IKAPI. (2010). Usaha Mikro, Kecil, dan Menengah. Semarang: Duta Nusindo.

Indiany, D. F., Rahmatika, D. N., \& Waskito, J. (2017). Jurnal analisis kinerja keuangan sebelum dan sesudah penerapan ppk-blud pada rsud kardinah. Multiplier, Vol. 1 No. 1. 
Julianto. Agung (2017). Pengaruh Tarif, Sosialisasi serta Pemahaman Perpajakan terhadap Kepatuhan Wajib Pajak UMKM di Kota Semarang. DKI Sripsi. Universitas Dianuswantoro.

Kadek, Megantara, dkk. (2017). Pengaruh Penghasilan Wajib Pajak, Sosialisasi Perpajakan, dan Kemauan Membayar Pajak Tehadap Kepatuahan Wajib Pajak Usahawan Atas Penerapan Peraturan Pemerintah No 46 Tahun 2013 (Studi pada KPP Pratama Singaraja). Jurnal Akuntansi, Vol. 7 No.1.

Kuncoro, Mudrajad. (2009). Metode Riset Untuk Bisnis \& Ekonomi. Jakarta: Erlangga.

Maharani, I. (Oktober 2015). Pengaruh Self Assessment System, Tingkat Pendidikan, dan Pelayanan Fiskus Terhadap Tingkat Kepatuhan Wajib Pajak UMKM di Kota Pekanbaru. Jurnal FEKON, Vol. 2 No. 2.

Mardiasmo. (2016). Perpajakan Edisi Terbaru 2016. Yogyakarta: Andi Offset.

Marina, Devi. (2015). Pengaruh pemeriksaan pajak terhadap kepatuhan wajib pajak badan (Suatu Studi pada Kantor Pelayanan Pajak Madya Bandung). Skripsi. Universitas Pasundan Bandung.

Mustofa, Fauzi Achmad, dkk. (2016). Pengaruh Pemahaman Perpajakan, Trif Pajak dan Asas Keadilan Terhadap Kepatuhan Wajib Pajak (Studi pada Wajib Pajak UMKM yang berada di Wilayah Kerja KPP Pratama Batu setelah di berlakukannya PP No. 46 Tahun 2013). Jurnal Perpajakan, Vol. 8 No.1.

Muziana, S. S. (2017). Analisis Fakto - Faktor yang Mempengaruhi Kepatuhan Pemilik Usaha Mikro, Kecil, dan Menengah (UMKM) dalam Memenuhi Kewajiban Perpajakan. Skripsi Program Sarjana, Universitas Pancasakti Tegal.

Ni Komang, Budi Kartini, dkk. (2017). Analisis Tingkat Pemahaman Wajib Pajak Industri Kecil dan Menengah Pada Pelaksanaan Self Assessment System dalam Melaksanakan Kewajiban Perpajakan (Studi pada Industri Kecil dan Menengah di Kecamatan Buleleng). Jurnal Akuntansi, Vol. 8 No.2.

Pertama, Adhit. (2016). Penerapan Peraturan Pemerintah Nomor 46 Tahun 2013 Pada Usaha Mikro, Kecil, dan Menengah di Kota Tegal (Studi Empiris pada Wajib Pajak Orang Pribadi Pelaku UMKM yang terdaftar di KPP Pratama Tegal). Skripsi Program Sarjana, Universitas Pancasakti Tegal.

PP, Menteri Keuangan Republik Indonesia. (2016). Penghasilan Kena Pajak. Peraturan Menteri Keuangan Tentang Penyesuaian Besarnya Penghasilan Kena Pajak. Jakarta: Berita Negara Republik Indonesia 2016 No. 950.

Prastowo, Yustinius. (2018, 22 Januari). Penurunan Tarif Pajak UMKM. Dipetik 29 Januari 2018, dari CNN Indonesia: https://www.cnnindonesia.com/ekono mi/20180122093909-532-270609/cita- dukung-usulan-pemerintah-diskon-pphukm.

Republik, Indonesia. (2008). Undang - Undang Republik Indonesia Nomor 36 Tahun 2008. Tentang Perubahan Ke Empat atas Undang - Undang No 7 Tahun 1983 Tentang Pajak Penghasilan. Jakarta: Lembaran Negara Republik Indonesia Tahun 2008, No. 133 Sekretariat Negara. 
Republik, Indonesia. (2008). Undang- Undang Republik Indonesia No.20 Tahun 2008. Tentang Usaha Mikro, Kecil dan Menengah. Jakarta: Lembaran Negara Republik Indonesia Tahun 2008, No. 93.

Republik, Indonesia. (2011). Peraturan Pemerintah No 46 Tahun 2013. Tentang Pajak Pengasilan Peredaran Bruto Tertentu. Jakarta : Susunan dalam satu Naskah Undang- Undang Perpajakan.

Republik, Indonesia. (2013). Undang-Undang PPh dan Peraturan Pelaksanaannya. Susunan dalam Satu Naskah Undang- Undang Pajak Penghasilan. Jakarta: Kemenku RI, Dirjen Pajak, Direktorat PPHM.

Saputri, Daniska Septiani. (2014). Pengaruuh Penerapan Self Assessment System Kemauan Membayar Pajak Terhadap Kepatuhan Wajib Pajak UMKM di Surakarta. Naskah Publikasi.

Sugiyono. (2012). Statistika Untuk Penelitian. Bandung : Alfabeta

Tjahjono, Achmad, dan Husein M.F. (2005). Perpajakan Edisi Ketiga. Yogyakarta: Akademi Manajemen Perusahaan YKPN.

UMKM, Kementrian Koperasi. (2016). Sandingan Data UMKM 2012-2013. Dipetik 29 Januari 2018, dari www.depkop.go.id: http://www.depkop.go.id/berita- informasi/data-informasi/data-umkm/

Wahyuningsih, Tri (2016). Pengaruh pemahaman wajib pajak, tarif pajak, mekanisme pembayaran pajak dan kesadaran wajib pajak terhadap kepatuhan wajib pajak umkm bidang mebel di surakarta. Skripsi. Institud Agama Islam Negeri Surakarta.

Wandira, Resa. (2017). Pengaruh pemeriksaan pajak, sanksi perpajakan, dan self Assessment system terhadap kepatuhan wajib pajak dan Dampaknya terhadap penerimaan pajak (survey pada kantor pelayanan pajak di wilayah kota bandung). Skripsi. Universitas Pasundan Bandung.

Widodo, Widi, dkk. (2010). Moralitas, Budaya, dan Kepatuhan Pajak. Bandung: Alfabeta. 